This item was submitted to Loughborough's Research Repository by the author.

Items in Figshare are protected by copyright, with all rights reserved, unless otherwise indicated.

\title{
Press scrums: some preliminary observations
}

PLEASE CITE THE PUBLISHED VERSION

PUBLISHER

(C) Ashgate

VERSION

AM (Accepted Manuscript)

LICENCE

CC BY-NC-ND 4.0

REPOSITORY RECORD

Watson, Patrick, and Christian Greiffenhagen. 2019. "Press Scrums: Some Preliminary Observations". figshare. https://hdl.handle.net/2134/14236. 
This item was submitted to Loughborough's Institutional Repository (https://dspace.lboro.ac.uk/) by the author and is made available under the following Creative Commons Licence conditions.

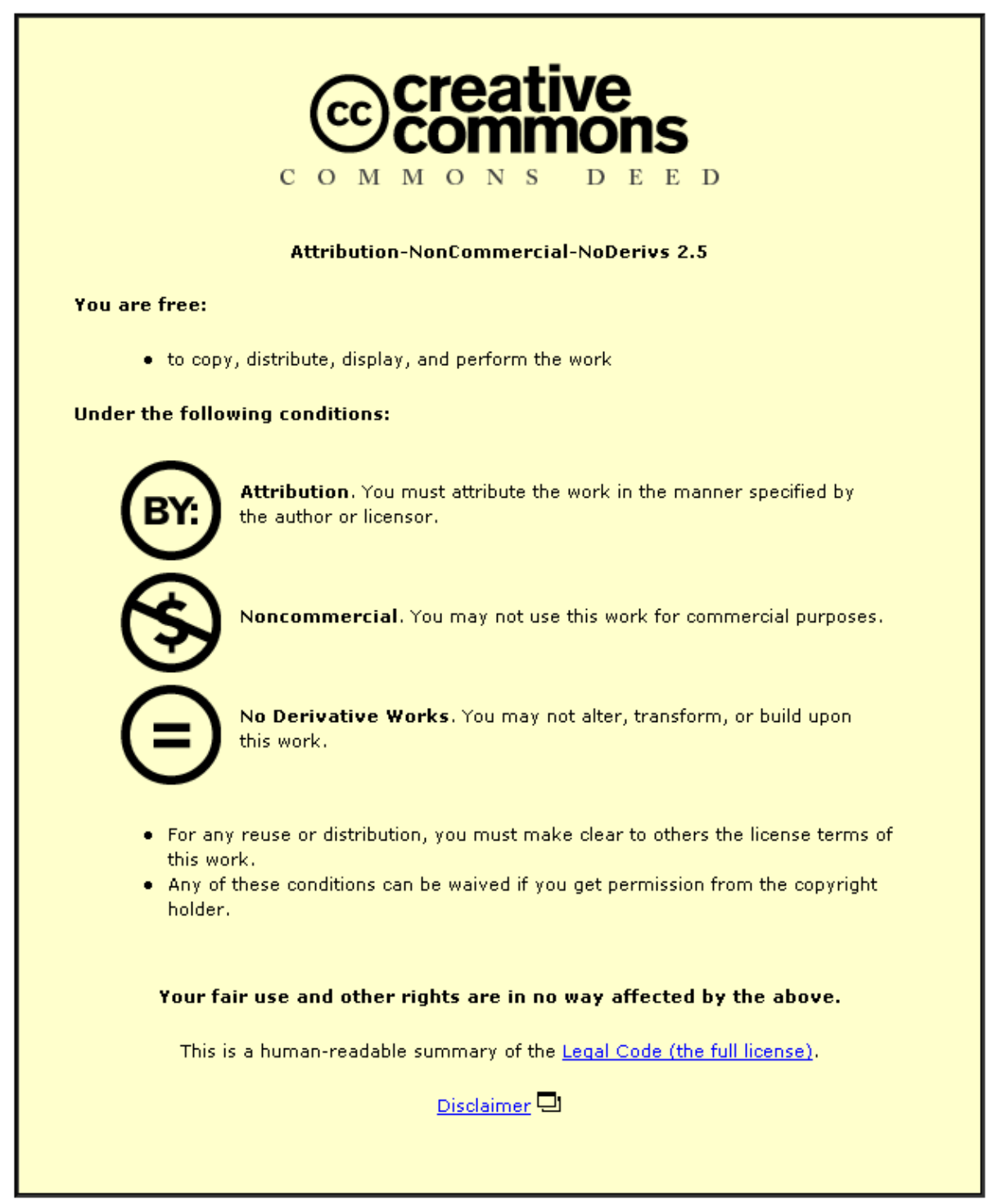

For the full text of this licence, please go to: http://creativecommons.org/licenses/by-nc-nd/2.5/ 


\section{Press Scrums: Some Preliminary Observations}

\section{Authors:}

Patrick Watson and Christian Greiffenhagen

\section{Address:}

School of Social Sciences

Arthur Lewis Building

University of Manchester

Manchester M13 9PL

UK

Version: February 9, 2009 


\section{Introduction}

In this paper we want to contribute to the study of the day-to-day practices of media operatives, focussing on a specific form of news gathering: the press scrum - quick, informal, unscripted encounters, in which reporters question, e.g., politicians about their views on particular topics ${ }^{1}$.

While in contemporary journalism, reporters are increasingly bound to their desks and rely on information that is sent to them in the form of wire copies, official statements, or press releases (cf., Davies, 2008), at other times materials have to be actively collected. Press scrums - a method of news data collection involving journalists from different media outlets physically bunched together so that they are all within hearing/recording distance of the person they want to talk to - are a common method for obtaining materials to compliment news stories. Such scrums are familiar scenes in places where reporters can hope to find people of interest: outside parliaments or public offices (law courts in particular), in front of the homes of people currently in the public eye, or following sporting events, to name a few.

Our case study focuses on the work of reporters covering the Ontario Legislative Assembly (OLA) in Toronto, Canada. Since the assembly is a reliable source of political news, local news outlets have reporters continually present throughout the legislature's working day. At various times of the day, particularly when politicians were known to be leaving the assembly

\footnotetext{
${ }^{1}$ The term 'scrum' (or 'scrummage') originates in rugby, where it designates "an ordered formation in which the two sets of forwards pack themselves together with their heads down and endeavour by pushing to work their opponents off the ball and break away with it or heel it out” (Oxford English Dictionary).
} 
to return to their offices, reporters would 'scrum' around them in the corridor and question them about recent events for subsequent newspaper reports or radio/television broadcasts.

Press scrums are akin to other forms of interactions between reporters and politicians, such as news interviews (e.g., Greatbatch, 1988; Clayman \& Heritage, 2002a) or press conferences (Schegloff, 1987; Clayman \& Heritage, 2000b). Like news interviews, they follow largely a question-answer format. However, whilst the news interview is meant to be "a finished product in its own right” (Clayman and Heritage, 2002a, p. 1), a press scrum is not broadcasted or published as a whole, but is rather meant to produce materials that can be reformulated into (part of) a news story or that can be quoted or replayed, providing 'sound bites' or 'pictures' which are valued formal elements of news reports.

Our analysis of press scrums is based on a two-month period of fieldwork, in which we were able to capture ten scrums. The study is thus in the tradition of ethnographies of news production and news gathering, but particularly influenced by more recent studies of news and media discourse, which examine audio- or video- recordings of media products in great detail in order to make visible the taken-for-granted practices of journalists (cf., Greiffenhagen, forthcoming).

There is a long tradition of ethnographies which have tried to open up the 'black box' of news production and gathering. While early studies were particularly concerned with issues of 'gatekeeping' (e.g., White, 1950), i.e., with questions of how and why certain stories are selected over others, in the late 1970s a number of ethnographers tried to reveal the processes through which the news are 'assembled', 'made', or 'manufactured' (e.g., Tuchman, 1978; Schlesinger, 1978; Golding and Elliott, 1979; Fishman, 1980). These studies wanted to demonstrate the social construction of the news, i.e., they argued that news, rather than being a simple mirror of reality, is at best only a selective version of it (with news stories being 
shaped as much by media values as by the 'facts' being reported). Whether through the examination of media output or through observations of decision making in news rooms, the dominant concern was to show that the news report represented no more than one possible and from the analyst's view, tendentious - rendering of the news materials.

These kinds of studies were soon rivalled by approaches drawing on the rapidly expanding interest in analyses of discourse, which originated in and drew from a variety of different disciplinary sources. In many cases, these studies sought to combine an interest in discourse with the increasingly prominent idea of the social sciences as essentially 'critical' disciplines. The rediscovered Frankfurt School and the increasing influence of Michel Foucault very powerfully propelled this critical direction. In Britain, Stuart Hall $(1980,1982)$ and the Glasgow University Media Group $(1976,1980)$ were particularly influential in demonstrating that the (linguistic) forms of representation adopted in news media were not neutral in the way that the media projected themselves to be, but rather embodied a 'hidden agenda' of communication, that of giving the dominant ideology an apparently congenial form. As the Glasgow University Media Group (1976, p. 1) put it: "the news is not a neutral product; [...] it is a sequence of socially manufactured messages, which carry many of the culturally dominant assumptions of our society”. The claim was not necessarily that journalists were personally biased, or deliberately deceitful, but dominant assumptions were embedded in and reproduced by news presentations. More recent approaches, such as critical linguistics (Fowler, 1991) and critical discourse analysis (Fairclough, 1995; Fairclough and Wodak, 1997; van Dijk, 1988) have aimed to demonstrate more specifically how linguistic factors contribute to, and are constitutive of, ideological representations of reality.

Alongside these 'critical' approaches to media discourse, other approaches to discourse, which could be labelled 'descriptive-explicative', have evolved. Researchers working in this 
tradition work with the same kind of data as their 'critical' colleagues, but put different questions to these data. Rather than asking, for example, whether language represents reality (successfully, objectively, ...), the question becomes what work the language is put to by participants. There are a variety of theoretical origins of such 'explicative-descriptive' studies, for example sociolinguistics (cf., Bell, 1991). However, our own study is most directly influenced by ethnomethodology and conversation analysis.

Ethnomethodology (Garfinkel, 1967) has as its aim to make visible the taken-for-granted practical methods that people use to accomplish various practices. Conversation analysis (Sacks, 1992; Sacks et al. 1974) has focussed on the methodic practices that are employed by conversationalists engaged in talk-in-interaction. This approach has been used to analyse a variety of media products: newspaper headlines (Lee, 1984), newspaper stories (Schenkein, 1979; Eglin and Hester, 2003; Barthélémy, 2003), letters-to-the-editor (Fitzgerald and Housley, 2006), television commercials (Francis and Hart, 1997), talk shows (Hutchby, 1996; Hester and Fitzgerald, 1999; Housley, 2002), or news interviews (Heritage, 1985; Greatbatch, 1988; Clayman and Heritage, 2002a).

In an important exchange (Schegloff, 1997, 1999a\&b; Billig, 1999a\&b), the conversation analyst Emanuel Schegloff has tried to clarify the difference between 'critical' and 'descriptive-explicative' approaches by arguing that the former employs the standard of the researcher to analyse materials, whilst the latter aims to ground the analysis in the standards and values exhibited by participants (see also Anderson and Sharrock, 1979). Thus while critical approaches employ an external standard to reveal factors that are 'hidden' or 'invisible' to participants, descriptive-explicative studies aim to exhibit the factors that participants themselves are attuned to. In the former, it is typically the researcher who decides whether a particular news product is 'neutral' or 'objective'. In contrast, researchers 
working within conversation analysis try to exhibit how participants themselves deal with issues of neutrality or objectivity. For example, Clayman and Heritage (2002a) in their study of news interviews demonstrate how interviewers actively work towards displaying their neutrality (e.g., by asking a question on behalf of third parties), and show how interviewees may, on occasion, challenge the neutralism of interviewers.

There have been very few studies that have tried to combine the focus of the ethnographic studies on the processes of news assembly with the fine-grained, real-time analysis that is typical of studies of media discourse. That is to say, most previous conversation analytic or ethnomethodological studies have analysed media products. Three notable exceptions are Heath and Nicholls's (1997) video-based examination of the production of news stories in an international news agency, Clayman and Reisner's (1998) study of how 'front page' stories are selected using audio-recordings of editorial conferences, and Broth’s (2004, 2006, forthcoming) investigation of the camera work during a live TV production based on video recordings of the control room. Following these, we have tried to base our own study on audio recordings of press scrums to exhibit the real-time creation of media materials. The aim has thus not been to demonstrate any hidden motives or ideologies on the part of journalists or politicians, but rather to show, through concrete examples, how it is that through the interaction between journalists and politicians they accomplish 'the news'.

\section{The scene}

Our analysis of press scrums is based on a two-month period of fieldwork in 2004 following press-, radio-, and television-reporters covering the Ontario Legislative Assembly (OLA). The fieldwork encompassed the time prior to and during the government's budget announcement. 
Reporters at the OLA were based in a lounge which sat between the government press office and the legislative chamber from which they were able to move to the press gallery in the debating chamber. Certain reporters (particularly those working for newspapers or the wire service) would spend time watching the debates, while others (predominantly television reporters) would show up in mid-afternoon, in time for when politicians would typically leave the debating chamber. Reporters received information through two official channels: the government press office, which would release a package each morning, and the party press offices, which would release their own news as well as comment on the government release $^{2}$. This, for the most part, informed the agenda of each of the press scrums. Reporters representing the wire services and newspapers would often be leafing through the press releases, watching a twenty-four hour news channel on the lounge television or wandering between the office, the lobby (where scrums were conducted) and the legislative chamber. In the mid afternoon, after the regular debating session in the legislative chamber had ended, the lobby of the OLA would become more active. Members of the press would assemble near the doors through which ministers and other politicians (e.g., shadow ministers) would leave the floor to return to their offices. As soon as the relevant politician was spotted, reporters would 'scrum' around her or him in order to ask a series of questions. In general, these scrums were brief (roughly one to ten minutes) and fluid affairs (reporters could come and go as they saw fit). The smallest scrum observed involved two reporters while in the largest about twenty reporters and camera operators were present. In the larger scrums, reporters

\footnotetext{
${ }^{2}$ There were any number of non-official channels, such as 'leaks', comments from outside authorities, stories relating to but not emanating from the OLA itself, etc. These could become topics in the scrums, but generally questions came from the government's agenda of the day (see Jaworski et al. [2004] for how leaks are presented, and contested, in radio news broadcasts).
}

Watson, P. and C. Greiffenhagen (2009). Press scrums: some preliminary observations. R. Fitzgerald and W. Housley (Eds.), Media, Policy and Interaction, pp. 115-135. Farnham: Ashgate. 
would stand in uncomfortable proximity to each other, often pressing against each other, using their fellow reporters to prop up their microphones and recorders. Some scrums were setup in advance, e.g., when reporters were informed by ministerial aides of the impending arrival of ministers in the lobby. In other scrums, crews and equipment transferred very quickly from one politician's location to the next, once the appropriate comment had been recorded. Following the scrums, politicians would return to their offices to conduct the rest of the day's business whilst reporters from television would head to edit suites and radio and print reporters would file their reports at offices off site.

An initial sense of press scrums can be gained from Transcript 1, which reproduces one scrum in its entirety.

\section{Transcript 1, Minister of Finance with Six Reporters (in entirety, Data Set 1)}

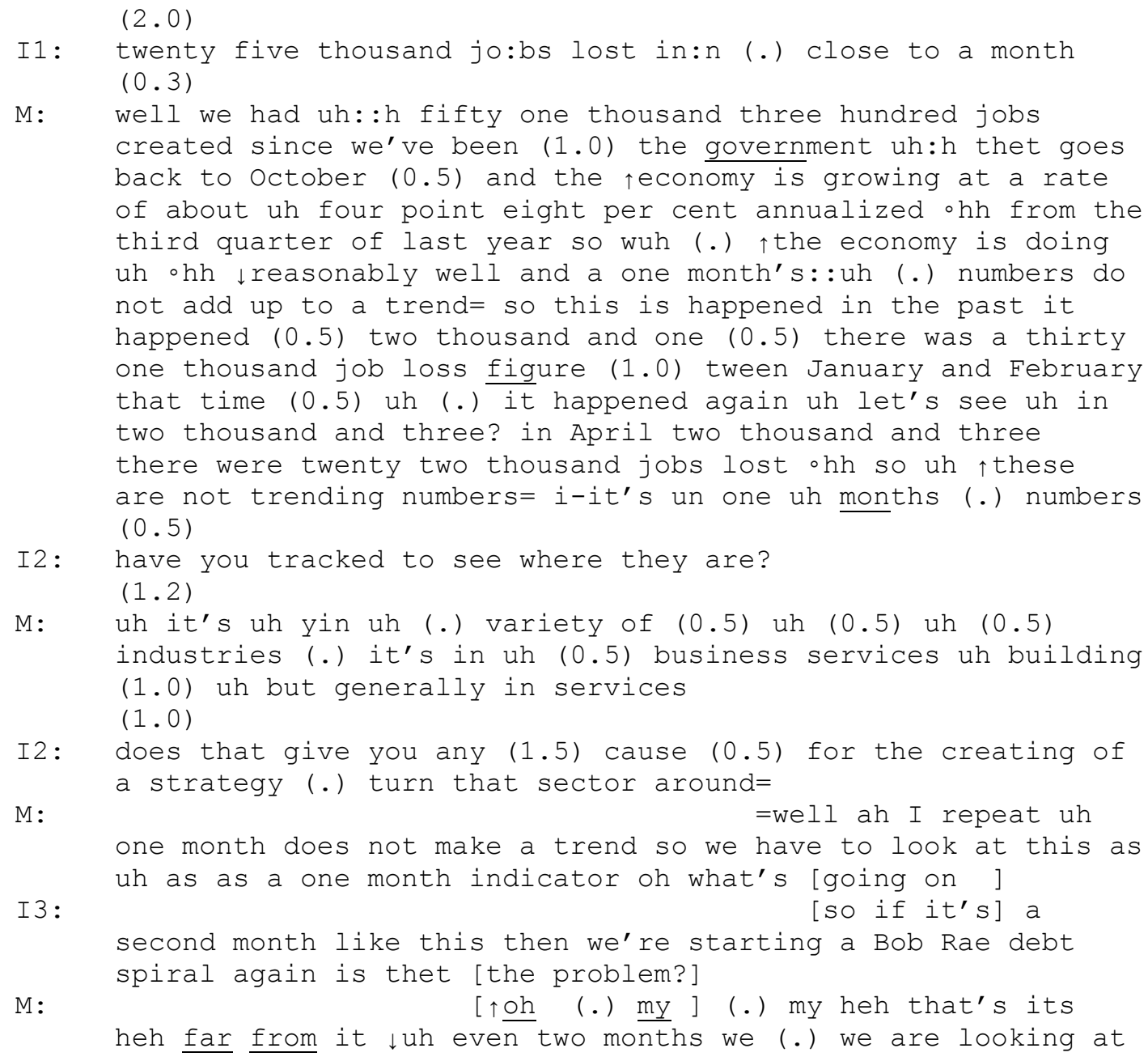




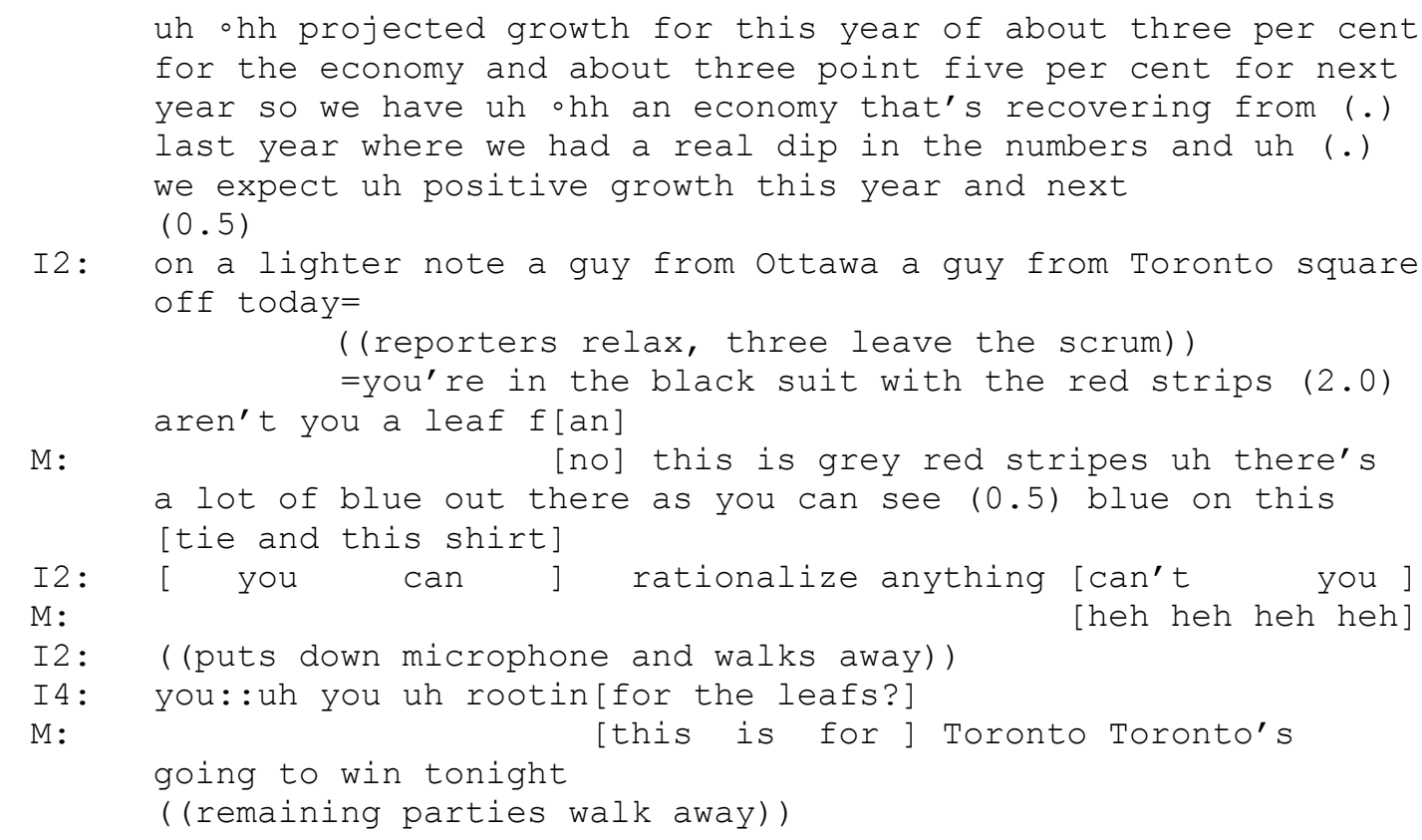

On the way back from the assembly to his office, the Minister of Finance is stopped by several reporters who question him about a report of declining employment figures over the previous quarter. What is at first perhaps surprising is the relative shortness of the scrum, lasting only one minute ten seconds. Also of note is the abrupt way in which the scrum begins: there are no greetings, introductory remarks, or lead-ins. Instead, upon the arrival of the minister, reporters gather around him and one reporter initiates the exchange through a question-like statement (line 2). Neither is the scrum brought to a formal close, but rather comes to completion with the politician's remark on Toronto's hockey team (lines 52-53), after which reporters simply walk away (line 54; although some reporters had already left before, see line 42).

The scrum is organised as a two-party turn-taking system between reporters and politicians, which mostly follows a question-answer format typical of news interviews (cf., Clayman and Heritage, 2002a), but also features challenge-comment pairs. For example, the reporter's first utterance in line 2, although not formulated as a question, is treated by the minister as one 
(and thus seems to be heard by him as containing an implicit "Would you comment on that ...?”). However, in contrast to news interviews, reporters' questions do not contain prefaces designed for an 'overhearing audience' (Heritage, 1985; Clayman and Heritage, 2002a, pp. 120-126) and presume significant shared knowledge on both sides. For example, the initial question (line 2) presupposes knowledge of a recent news story (the job losses in the month prior) and is based on the assumption that the minister is an appropriate person to ask for comment on that story (since it was not a formal topic of discussion on the floor of the legislature that morning).

No discernible order as to who of the reporters gets to ask a question is apparent, but this lack of predetermined sequence of questioners does not imply that scrums are chaotic. Instead, different reporters ask questions around the same topic. For example, I2's question in line 18 can be heard as a follow-up to I1's question in line 2. Reporters do not seem to compete for the right to ask questions, but rather collaborate with each other. For example, it is generally accepted and expected that television reporters would ask the first question. The general idea, as reporters described it, is to ask the type of questions that would unnerve the politician; other reporters would often allow a single reporter to use whatever necessary time in the scrum if they were succeeding at doing so.

Looking at the scrum in its entirety, it becomes clear that this is a routine affair. The absence of any setup, the relative brevity and abruptness of questions, and the limited amount of time spent conducting the scrum all point to the fact that these exchanges occur frequently and are part of the mundane business of both politicians and reporters. 


\section{Openings}

Activities have beginnings or openings, which frequently are marked in a variety of ways (cf., Turner, 1972, p. 369; Sacks, 1992, p. 105). Some activities are verbally marked, for example, teachers" "good morning” or “come on settle down" in classrooms (Payne, 1976; Greiffenhagen, 2008) or the announcement "Be upstanding in court..." in courtrooms (Atkinson and Drew, 1979, pp. 87-91). Press scrums typically start with a reporter's first question. In other words, there are no greetings, preambles or requests to whether reporters could ask a question. Instead, almost all scrums begin as the one in Transcript 1: with one reporter asking a question.

Of course, both parties, reporters and the politician, have to work to be in a position where one reporter can ask a question. Thus there are elaborate 'pre-beginnings', in which both parties 'get into position'. Reporters gather in the lobby outside the debating chambers about half an hour before they expect the ministers or other politicians of interest to leave the floor ${ }^{3}$.

Sometimes reporters are already in a state of readiness, waiting for the politician to exit, in which case the politician walks to the designated position facing the reporters. At other times, politicians stand in the lobby waiting for the reporters to assemble around them. Reporters would wait for those politicians who were most likely to be the potential source of newsworthy material. In this setting, reporters always gathered around the exit of the

\footnotetext{
${ }^{3}$ Ministers would leave through the session, after they concluded their business on the floor, but the session could be expected to continue after they had left. It was typically only one or two politicians (minister and opposition member) who would leave around the same time.
}

Watson, P. and C. Greiffenhagen (2009). Press scrums: some preliminary observations. R. Fitzgerald and W. Housley (Eds.), Media, Policy and Interaction, pp. 115-135. Farnham: Ashgate. 
government party and would only subsequently walk up to opposition members who had left the chamber.

A politician walking up to the reporters signals that the scrum is about to begin. It is at this point that the reporters - and the researcher - would start their recorders. Most recordings gathered from the site therefore start with a silence before the first turn (as in line 1 in Transcript 1). This silence represents the phase in which participants are 'almost ready', but are not yet starting the verbal exchange.

Reporters not only check whether the politician is ready to be asked a question, but also whether fellow reporters are ready (e.g., have positioned themselves appropriately and turned on their equipment). At times, this is explicitly addressed. For example, in the following transcript, one reporter (I1) is talking to another reporter (I3) who is having problems getting his recording device to start. A third reporter (I2) is waiting for I3, before producing the first question (line 3).

Transcript 2, Minister of Health and 5 reporters (lines 1 - 7 of 92 lines, Data Set 4)

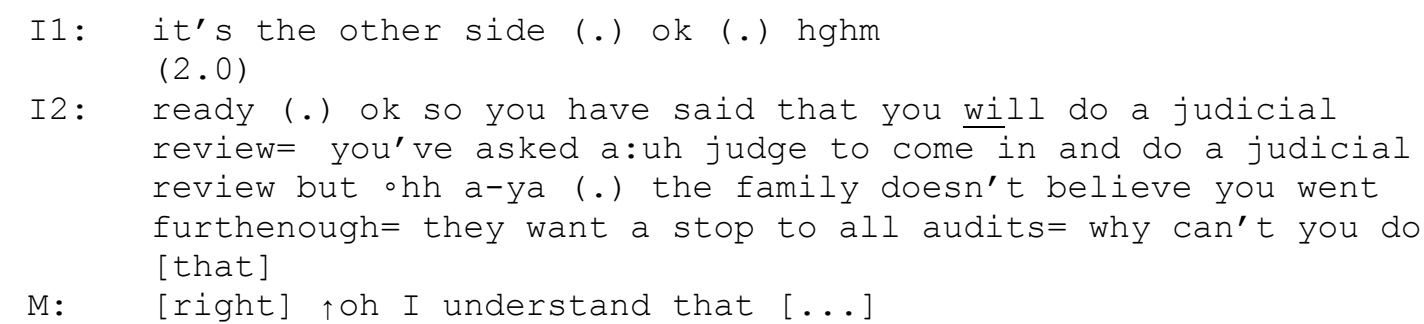

In another instance (Transcript 3), the minister walks up to the assembled press scrum. Upon his arrival, the television reporter (I1) is informed by the camera operator that there is a small problem with the camera. Consequently, rather than asking the first question, the reporter asks the whole scrum to "hold on" (line 2). The eventual start is so long forthcoming that the politician produces a rare greeting (line 6), which is answered by one of the reporters (line 8). 
Transcript 3, Minister of Health and 15+ reporters (line 1 - 12 of 222 lines, Data Set 5)

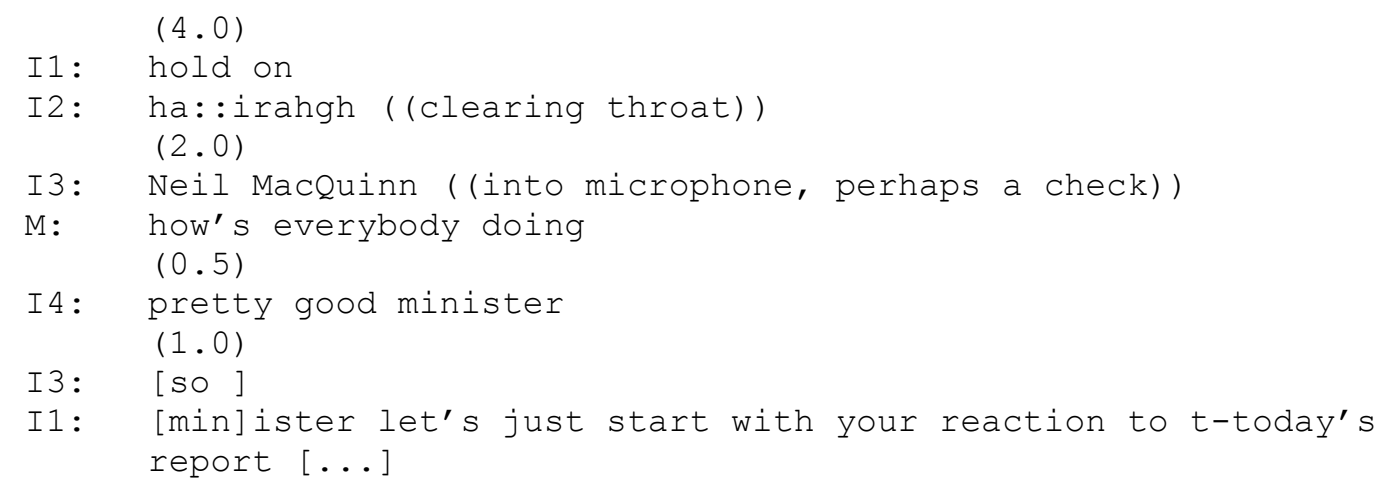

Although in this instance all parties are in the right physical position for the questioning to begin in line 1 , the problem with the television camera delays the expected first question. In other words, both reporters and politician monitor the group to see whether everybody is 'ready'. It is not the case that the scrum could not start without every reporter being ready, but reporters are willing to wait for their colleagues to adjust their devices before proceeding with the scrum.

As mentioned, the beginnings of scrums rarely include greetings, pleasantries, or requests, but reporters rather go straight to questioning. All parties know what Schenkein (1971, pp. 30-31) refers to as the 'reason' for the encounter, which includes expectations as to 'why' the encounter has been arranged, 'what' the projected conversation will be about, and 'how' the participants will spend time in conversation with each other (p. 30). In Schenkein's case, a conversation between an insurance salesman and a graduate student, the conversation is the product of a pre-arranged appointment for the delivery of a promotional gift wallet offered by the insurance company to prospective clients. Although both parties know that more than the delivery of the wallet will take place (buying/selling of a life insurance policy), this is not what the parties immediately talked about. Instead, there is a series of greetings and other talk, in the course of which the parties are 'getting to' the reason for the conversation. In contrast, an elaborate or indirect 'getting to' is unnecessary in press scrums. There are good 
reasons for this, since in contrast to the insurance case parties already know each other. It is also generally accepted that, due to their busy schedules, ministers are only available for a few minutes and will have to move on quickly. Pleasantries are therefore an unwanted intrusion into the scrum's time with the minister (see also Fitzgerald and Housley [2002] for how hosts during radio phone-ins may launch straight into a question).

Questions are also formulated in a very succinct and compact manner and based on a variety of presuppositions (which includes the issues that are currently relevant, why the interviewed person is in a position to comment on it, and what aspects might be explored). In Transcript 1, for example, the reporter does not explain that the relevance of his question (on line 2) is premised on the report released that morning (which pointed to rising unemployment figures) and the minister is not surprised by the question (since he presumably understands that with a report mentioning rising unemployment, reporters will ask what the government will do about it). Similarly, in the next transcript, the reporter's first question (lines 2-5) asks about the "OPG / hydro one deal", but does not mention that this question is prompted by the government's decision to make public the salaries of employees of the recently privatised electricity utility.

Transcript 4, Leader of Third Party with 5 reporters (lines 1 - 8 of 185 lines, Data Set 2)

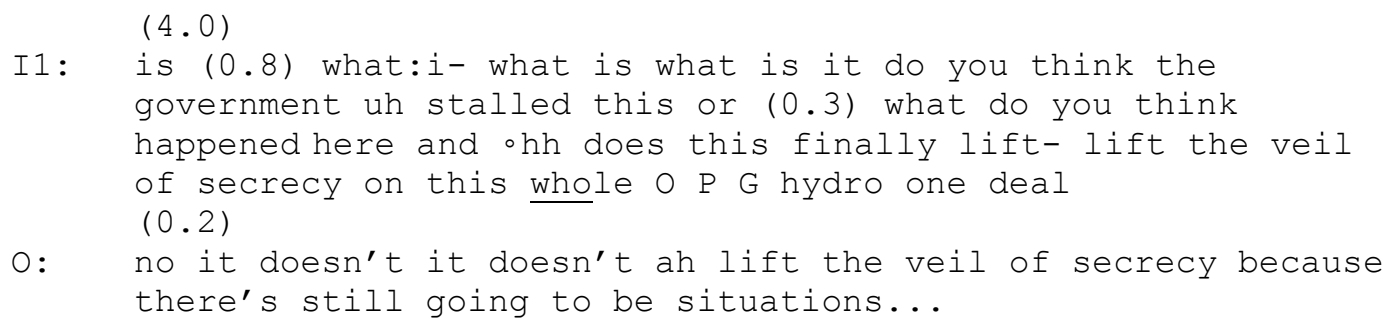

The reporter's question (lines 2-5) is opaque without sufficient background information. There is no explication of what had just happened, why this was a relevant question to ask, or how the characterisation of the deal (in terms of secrecy) is a relevant one. However, the 
interviewee has no difficulty understanding what the question is asking, thereby displaying that the reporter's question is designed for the politician - rather than a potential news audience.

Sacks (1992, p. 564) remarked that conversationalists operate under the maxim "design your talk to another with an orientation to what you know they know”. The way reporters design their questions in press scrums is in relation to the knowledge of the people in the room (the politician and the other reporters). It is interesting to compare this with broadcast news interviews, where much talk is not designed as such, since it is not a conversation between interviewer and interviewee, but a conversation for the benefit of an 'overhearing audience'. Clayman and Heritage (2002a, p. 60) note that, for example, news interviews are characterised by very elaborate openings prior to the interviewer's first question. These openings typically consists of (1) headline (detailing the topic for discussion), (2) background (providing the information necessary to understand the questioning), and (3) lead-in (in which interviewees are introduced), where this opening "is addressed explicitly to the audience rather than to the interviewee” (p. 59). Furthermore, interviewees are frequently introduced in a way that identifies why they are relevant to the topic under the discussion, e.g., as ‘participant', 'expert', or 'advocate’ (pp. 68-72). Similarly, in talk shows “guests are introduced as incumbents of membership categories which are recognizably relevant to the topic of the show" (Hester and Fitzgerald, 1999, p. 177). The reason for such introductions is that the talk produced is predominantly designed for an 'overhearing audience', which frequently needs more background information than the actual parties in the room.

In contrast, the compactness of questions in press scrums and the absence of elaborate introductions demonstrate that the scrum is not meant to be a media product in itself, but part of the gathering of materials for eventual products. Questions in press scrums are thus not 
designed to be understood by the eventual audience specifically, but by the parties present in the scrum (e.g., the politician). These questions are meant to elicit materials which, if framed in the appropriate manner will be relevant to the audience. Clayman and Heritage (2002a) characterise the news interview "as a 'strictly business' encounter that has been planned in advance and is now being orchestrated on behalf of the media audience” (p. 68). Press scrums are similarly 'business-like', but they are not directly arranged for an overhearing media audience.

\section{Closings}

Scrums can be brought to an end by either side, i.e., by politicians or reporters. In the case of the former, it is typically not the politician who explicitly imposes a limit or says that he has to go, but instead the aide accompanying the politician. One frequent practice is to indicate that the politician would only take a few more questions.

Transcript 5, Minister of Health and 10 Reporters (lines 189 - 196 of 231, Data Set 7)

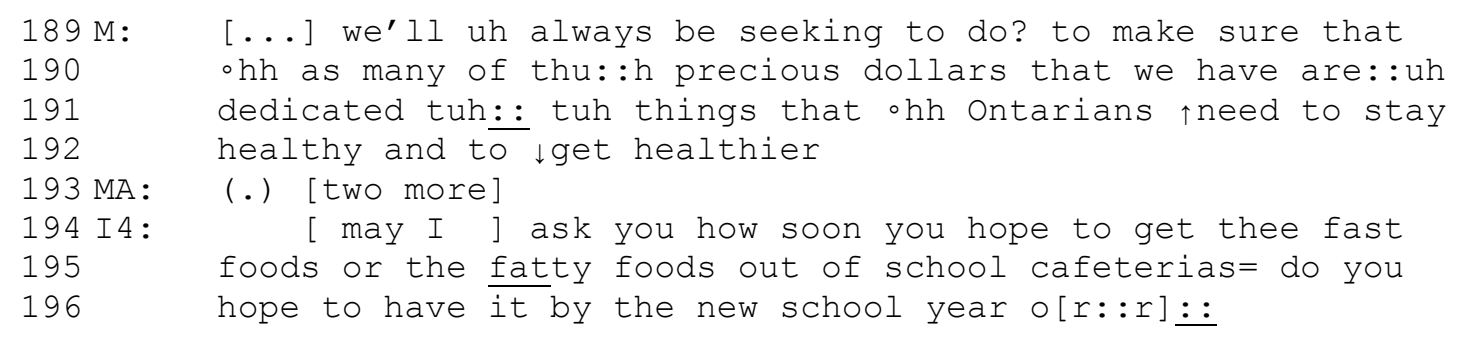

In this transcript, the minister produces a relatively long answer (lines 176-192). Once the minister has finished the answer, and after a short pause, the minister's aide makes a quick remark (simultaneously with one of the reporters asking the next question), indicating that the minister would take two more questions (line 193). Similarly in the next transcript:

Transcript 6, Minister of Health and 15+ Reporters (lines 194 -201 of 227, Data Set 3)

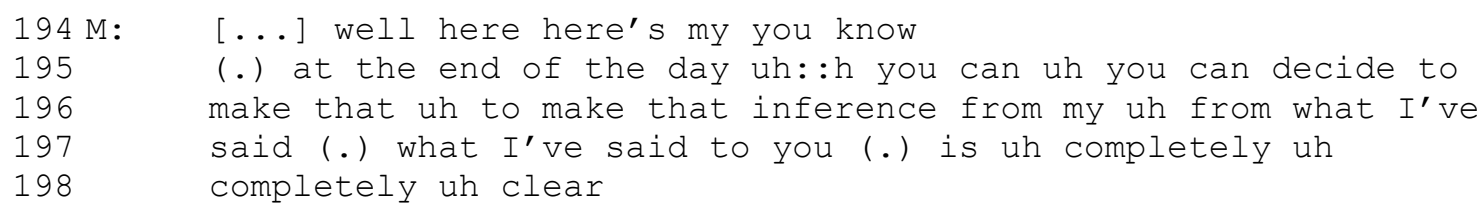


$\begin{array}{ll}199 \mathrm{MA}: & \text { [two more questions thanks] } \\ 200 \mathrm{I} 4: & {[\text { so back to these p threes] there'll be no new p threes }} \\ 201 & (0.8)\end{array}$

Dealing with the press is only one of a politician's daily tasks. Although politicians are obligated to talk to the press, this does not have to occur for extended periods of time. The aides' interjections ("two more", "two more questions please”) are a way of acknowledging that reporters would like to ask more questions, but reminding them that the minister has other things to do. Having the aides rather than the politician himself 'wind down' (Clayman and Heritage, 2002a, p. 76) the scrum, also provides them with a way to get ministers from difficult situations. The press secretary of the OLA indicated that as part of the media training for minister and their staff, aides would be instructed on how to monitor the minister's performance, and to spot trouble signs in the questions and responses. Although no evidence of this occurring appears in our data, reporters were aware that this could happen, and did not appreciate the fact that ministers could escape if the reporters were getting too close to a negative event.

If a scrum is ended by a reporter, this is not accomplished through any formal markers. There are typically no farewells or thank yous at the end of a scrum, but rather the scrum simply ends with the final answer of the politician. It is instructive to compare this with the closings of news interviews, which are also characterised through an absence of ritualized farewells, but which do involve the interviewers thanking the interviewees for their participation (Clayman and Heritage, 2002a, p. 74). These thank yous allow the interviewer to close the interview in accordance with a predetermined and fixed time frame, sometimes even cutting into the interviewee's final answer. The rigidity of scheduling with live-to-air broadcasts is not an issue with the scrum, as the completed product only involves partial segments of the scrum's entirety and as a result no marker is required to signal to the interviewee that the time for speaking has concluded. 
In the scrums observed, rather than using a verbal marker (such as "thank you”) to indicate that reporters want to end a scrum, reporters would instead indicate through bodily behaviour that the questions were exhausted for today. For example, some reporters would stop their equipment and move away while the other reporters continued questioning. In particular, television reporters would often leave after two or three minutes. Schegloff and Sacks (1973) remark on such 'non-verbal' means of closing:

[...] there may be some conversation whose closing is accomplished solely by 'non-verbal means' (as when one of the parties has become involved in a side conversation, and his erstwhile coparticipant seeks to depart without interrupting). (p. 323, footnote 20)

The visible behaviour of reporters (stopping equipment, closing notepads, walking away) indicates to the politician that the interview is about to end and therefore no verbal markers are necessary ${ }^{4}$. For example, in Transcript 1 , it is apparent to all parties that the minister's answer (lines 52-53) would end the scrum, which is exhibited by reporters turning off their equipment and starting to turn away. The following scrum is also not 'formally' closed, but comes to an end with the minister's affirmative answer:

Transcript 7, Minister of Health and 15+ reporters (lines 216 - 222 of 222, Data Set 5)

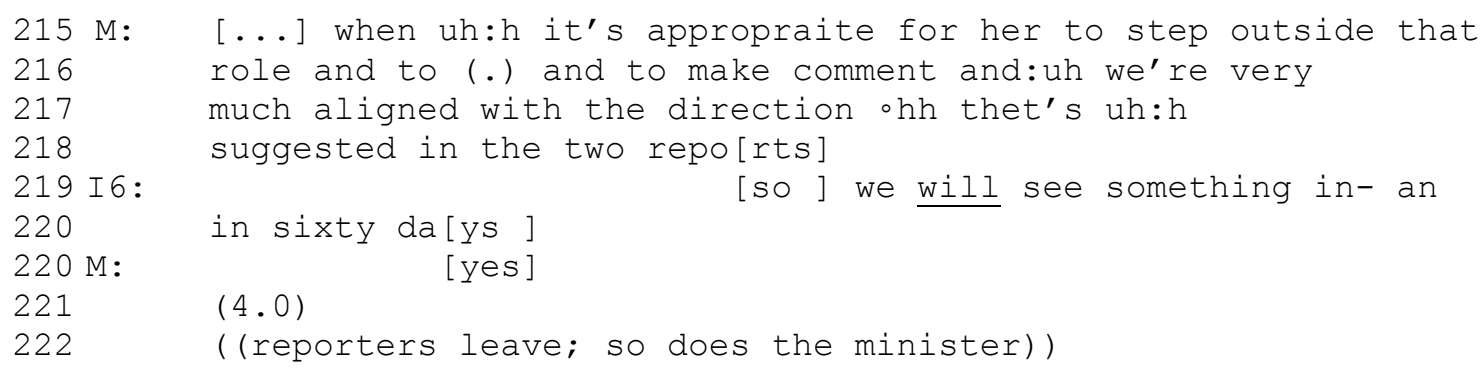

\footnotetext{
${ }^{4}$ See Laurier (2008) for an analysis of how conversationalists in cafes can use “silent yet visible ways” (p. 174) to indicate that an ending may be immanent (e.g., pushing a coffee cup away to indicate that one has finished drinking).
} 
In this example, the Minister of Health provides a long answer (lines 199-218) to a reporter’s question. The reporter produces a quick follow-up confirmation-seeking statement, which is answered succinctly by the minister (line 220). Since no further question is forthcoming and reporters start to 'pack up', the minister walks away without any explicit verbal termination of the scrum.

Although verbal closings to scrums are infrequent, that a closing was forthcoming was occasionally foreshadowed in a change of topic or questioning. Reporters can indicate that a closing was forthcoming by asking a question that is hearably slightly 'off-topic', e.g., more humorous or away from the more serious news of the day. For example, in Transcript 1; one of the reporters initiates the final topic through the utterance "On a lighter note [...]” (line 40), before launching into a question about the minister's allegiance to one of the provinces two hockey teams, who were playing each other at the time. Although the exchange continues for a few more lines, the reporter's initial question (line 40) indicates that a closing was immanent. Similarly:

Transcript 8, Opposition Finance Critic with 15+ reporters (lines 163 - 170 of 191, Data Set 8)

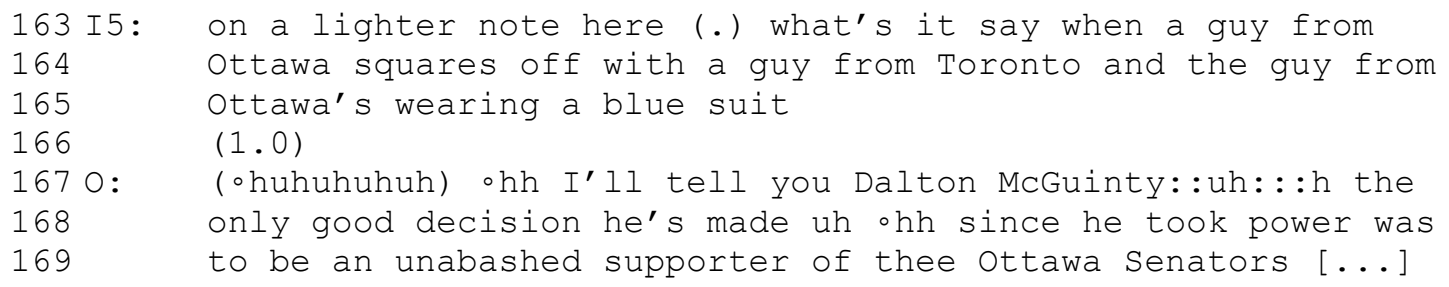

Again, the preface "on a lighter note” (line 163) indicates that the formal business of the day has been fulfilled, but since the politician did not yet seem desperate to move on, there was an opportunity for a humorous topic to be pursued, which would only be of interest to a few reporters. Some reporters took this as an occasion to conclude, and either relaxed their posture or exited the scrum altogether. 


\section{Routine nature of scrums}

The popular image of press scrums is one of an aggressive, exciting encounter between the press and a person of interest. However, this picture is based on extraordinary scrums, where the scrum itself becomes a newsworthy item. This was not often the case at the OLA, where scrums were part of the mundane, routine work of news reporters. This routineness was institutionally built in: this was the place and time where and when scrums were supposed to happen. Politicians were not surprised by the fact that reporters were waiting for them.

Much of the time, the gathered materials were also mundane to reporters. Frequently what politicians had to say was not itself the main news materials, but provided story filling, giving government reactions, opposition responses, pictures, sound bites and the like. Big announcements by the government would be handled through press conferences, which were attended by the same press corps. On rare occasions politicians would meet with individual members of the press shortly after a scrum. What was actually said in a scrum was rarely extraordinary (not a 'scoop'), but typically ended up complementing other materials (gathered through press releases, etc.). Published or broadcast news stories are often a heterogeneous construction of different materials from different sources, and the scrum contributed accordingly.

Almost all of the reporters at the OLA were on full time assignment. They would spend the vast majority of their working day preparing stories in various ways, and would not be expected to cover events outside of the realm of provincial politics as a matter of course. Although a prestigious job in its own right, some reporters, particularly those working for larger television networks, would aspire to covering national politics. When some of the reporters were asked about the less desirable aspects of the job, they did not mind that there 
was a low probability that they would get a headline quote, but they did mind it when colleagues were unaware of their lack of personal hygiene, or were wearing too heavy of a scent. Since reporters had to do this every day, they wanted to work in as pleasant of an environment as possible.

Scrums are everyday occurrences. As remarked above, this means that reporters could get straight to business and that both parties could presume a 'history known in common', since it could be expected that most people will have been present at previous press scrums. So in the following transcript, a minister introduces his answer as a repeat of an answer that he had given already yesterday:

Transcript 9, Minister of Health 15+ reporters, (line 142 - 147 of 222, Data Set5)

142 17: how come the province doesn't have a pandemic flu plan in

143 place (.) thuh federal government does local government from

144 uh: :h two different (.) local cities are working on them

145 so where's the province

$146 \mathrm{M}$ : wull people are working uh-I think I said yesterday Mike in

147 answer to a question that I re:ally belie: :ve that ohh the

148 pandamic flu pla- flu plan is about continuous improvement

$149 \quad[\ldots]$

The reporter asks about the pandemic flu plan of the Province (a topic which had become relevant due to the recent SARS crisis) and mentions that both the federal government and two municipal governments have begun developing such plans. The minister, rather than answering the question directly, alludes to statements made on the previous day (in relation to the release of a government report). Similarly, in the following transcript, the minister makes reference to previous scrums:

Transcript 10, Minister of Health and 10 reporters, line (132 - 145 of 231, Data Set 7)

132 I7: whuh $\uparrow$ why do $\downarrow$ you want to

133 increase the number of uh: :h working poor in ontario by uh:h

134 allowing p trees uh: :h (.) cause that's the message that's

135

$136 \mathrm{M}:$

137 I7:

coming from uh:h some union leaders and u[h:h ] $\uparrow$ the

pharma [cist ] $\mathrm{s}=$

[whuah]

Watson, P. and C. Greiffenhagen (2009). Press scrums: some preliminary observations. R. Fitzgerald and W. Housley (Eds.), Media, Policy and Interaction, pp. 115-135. Farnham: Ashgate. 
$138 \mathrm{M}$ :

139 I7:

$140 \mathrm{M}$ :

141

142

143

144

145

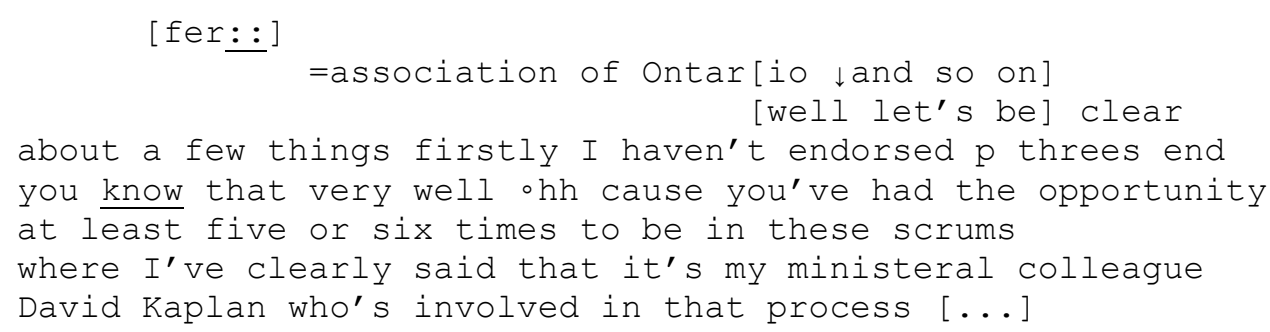

The reporter asks a relatively heavy-handed question, which includes the presumption that the government is deliberately aiming to decrease the wages of public health employees (which is typically assumed to be the result of privatisation). The minister is quick to distance himself from the implication by reminding reporters that he has not personally endorsed privatisation (line 141) and also that it is not even his decision to make. In other words, it is not his place to speak for the government on these matters.

In these exchanges, not only do ministers refer to previous encounters with the reporters, they also can use these encounters as a defensive manoeuvre in order to attenuate the question (“I’ve answered this already...”). Although it is common for reporters to ask a question repeatedly (either in the same scrum or on different occasions) in order to try to get new information or possibly catch the politicians contradicting themselves, politicians use this as a way of converting a particular question into one that has already been answered. This is then an economical manner in which politicians can say that although they are aware that reporters are hoping for a 'non-standard' answer, if they continue to ask questions along these lines, they will only get repeats of the 'standard' response).

\section{Scrums as collaboration}

There is clearly some degree of competition between different media (e.g., television versus print) and different media outlets (e.g., Toronto Star and Globe \& Mail). There is a need for exclusivity in certain cases (witness the search for exclusive photographs of celebrities). 
However, not all aspects of news gathering are competitive in nature. Many of the materials through which news is assembled are available to everyone (e.g., press releases, press conferences, or public reports). The primary objective at the OLA was to secure adequate amounts of materials and although it may be beneficial to have exclusive materials, this was generally not necessary. Since what is said in scrums is available to all those who were present, scrums are characterised by a high degree of collaboration among reporters. Everyone is within hearing distance of what is said and the fact that a particular reporter asks a question does not give her or him proprietorship over the answer. Consequently, it is generally accepted that reporters would benefit by working together.

This collaboration among reporters becomes visible in a variety of ways. When discussing openings we had already remarked that reporters typically wait for other reporters to be ready rather than racing ahead to gather materials which would not be recorded by others. There is also collaboration between different kinds of media. Reporters oriented to a rule of 'television people go first' and allowed them to ask the first question. The reason for this is that television people only needed small amounts of footage to air alongside a more in-depth story, and that camera operators suffered under the load of their equipment. Since television cameras are most difficult to setup, allowing them to ask the first question also almost always ensured that everyone else was ready to begin.

Reporters in the press scrum did not resemble the aggressive, guarded and individualistic stereotype (e.g., Smith, 1980). 'Getting materials' was more easily achieved when each reporter oriented to the team and treated the assembly as such. This is nicely demonstrated in Transcript 1, in which lines 2-39 all centre on one particular topic (job losses). Although reporter I1 introduces the topic with the scrum's first question (line 2), it is the second reporter I2 who produces a first (line 18) and a second (line 24-25) follow-up question, before 
yet another reporter, I3, asks the final follow-up question (lines 29-31). What this demonstrates is that reporters are working together to explore a topic, i.e., they collaboratively pursue a line of questioning ${ }^{5}$. This can also be seen in the following excerpt:

Transcript 11, Minister of Health and 15+ Reporters (lines 16 - 21 of 227, Data Set 3)

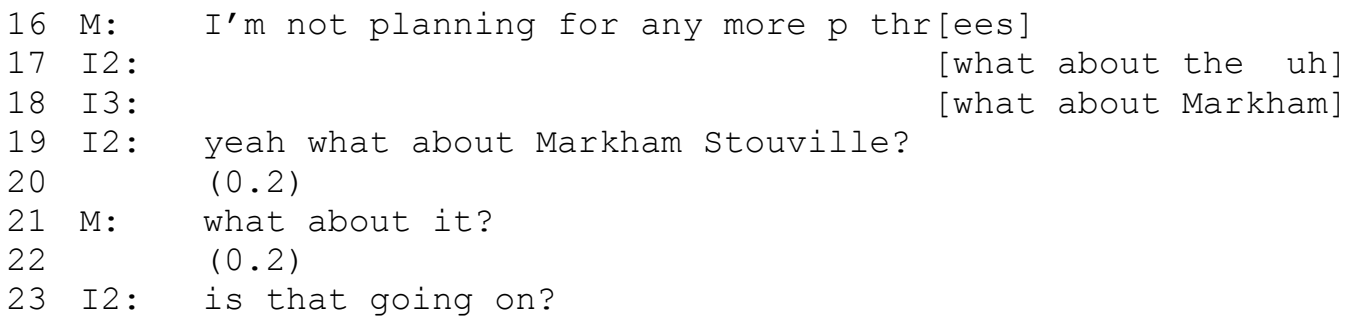

In this instance, two reporters (I2 and I3) both start to ask the next questions (lines 17 and 18). However, there is no visible competition over whom the question belongs. Once I3 has formulated his question (“what about Markham”), I2 agrees that this is a relevant question to ask (“yeah what about Markham Stouville?”).

Reporters also tend to refer to themselves as a collective. In informal interviews during the fieldwork, reporters would use "we" rather than "I" to describe their activities (e.g., "we like to get up close”; "we were upset when the premier stopped doing press scrums”). Also, in one scrum, the minister's answer (that he was not planning for any more public-private partnerships) is treated by one of the reporters as surprising to all reporters (line 54), rather than as only surprising to the reporter asking the question:

Transcript 12, Minister of Health and 15+ Reporters (lines $49-57$ of 227, Data Set 3)

\footnotetext{
${ }^{5}$ Schegloff (1987, p. 224) notes that reporters during press conferences, in which it was the politician who nominated the next reporter who could ask a question, had to decide whether to use their turn to follow up on the preceding question-answer exchange (of another reporter) or to ask their own (prepared) question.
} 


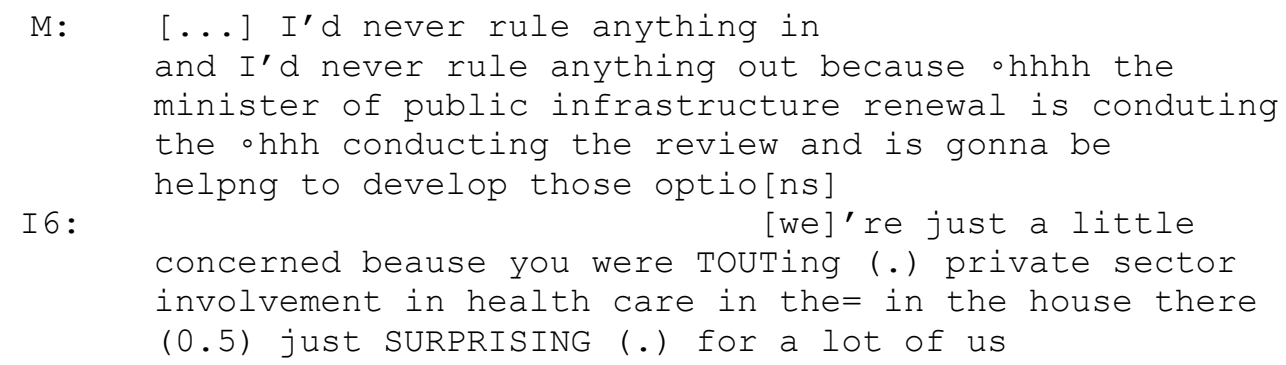

In sum, there is a strong communal sense of reporters in scrums, with no proprietary rights over who elicits information. The differentiation between media outlets occurs after the materials had been generated in the scrum (when materials can be 'individualised' by saying, for example, “The Minister of Health yesterday told the Globe”, which doesn’t mention that he also told other reporters).

\section{Conclusion}

As mentioned in the introduction, most studies of media discourse focus on media products, such as newspaper or radio/television broadcasts. Our study is an attempt to study the discursive practices of the processes through which such products are assembled. This has so far primarily been studied through ethnographic investigations - with the exception of Heath and Nicholls's (1997) analysis of the real-time production of stories in a news agency, Clayman and Reisner's (1998) research on 'gatekeeping-in-action' in editorial conference and Broth's (2004, 2008, forthcoming) examination of the editing practices in a control during a live television broadcast.

A consequence of this shift from product to process is that it brings the journalist back into the analysis, since journalistic practices could perhaps be seen as the 'missing what' of recent studies of media discourse. What we would suggest is that by understanding the questions of how media products are collected, assembled and disseminated, the understanding of the fifth estate as an institution will become more sophisticated and accurate. It is reportedly not uncommon for media operatives to accuse academics of talking past the issues or 
misrepresenting their practices (e.g., Ericson et al., 1987) and by taking seriously the role of reporters, editors and other practitioners of media production, this weakness can be overcome.

Press scrums are one way through which journalists gather materials for their stories. Scrums resemble other forms of media interaction in their question-answer format, but nevertheless constitute a particular speech-exchange system (with similarities to press conferences, perhaps) in which we have several questioners and only one respondent. Reporters' questions are not of one kind, but include, for example, requests for further information, clarifications, as well as probes and challenges. This reflects the different aims and purposes that reporters pursue during a scrum. Perhaps predominantly they would try to gather materials for stories-already-in-process (as, e.g., prompted through a press release). However, they would also try to 'find', or even generate, stories in the scrum, through their questioning, putting politicians in positions where they might say newsworthy things.

One way in which our study could be usefully extended would be to 'follow stories around' (to adopt the subtitle of Latour, 1987), i.e., to investigate the different ways in which the materials gathered in the scrum end up in newspaper articles or radio/television broadcasts (as direct quotes, paraphrases, etc.). As we stated above, we believe this would lead to a more complete picture of both the media's function and functionality within a broader society. The process of understanding the news in completed form is understandably complimented by a comprehension of how that form came about as a collaborative effort between news makers and news reporters.

\section{References}

Anderson, D. C. and W. W. Sharrock (1979). Biasing the news: technical issues in 'media studies'. Sociology 13 (3), 367-385.

Atkinson, J. M. and P. Drew (1979). Order in Court: The Organization of Verbal Interaction in Judicial Settings. London: Macmillan. 
Barthélémy, M. (2003). Temporal perspectives in the practical-textual handling of a European public problem. Social Science Information 42 (3), 403-430.

Bell, A. (1991). The Language of News Media. Oxford: Blackwell.

Billig, M. (1999a). Whose terms? whose ordinariness? rhetoric and ideology in conversation analysis. Discourse \& Society 10 (4), 543-558.

Billig, M. (1999b). Conversation analysis and the claims of naivety. Discourse \& Society 10 (4), 572576.

Broth, M. (2004). The production of a live TV-interview through mediated interaction. In C. van Dijkum, J. Blasius, H. Kleijer, and B. van Hilten (Eds.), Recent Developments and Applications in Social Research Methodology (Proceedings of the Sixth International Conference on Logic and Methodology, August 17-20, 2004, Amsterdam). Amsterdam: SISWO. Available at http://icar.univlyon2.fr/ecole thematique/contaci/documents/broth/Broth_Mediated interaction.pdf

Broth, M. (2008). The 'listening shot' as a collaborative practice for categorizing studio participants in a live TV-production. Ethnographic Studies 10, 69-88.

Broth, M. (forthcoming). Seeing through screens, hearing through speakers: Managing distant studio space in television control room interaction. Journal of Pragmatics.

Clayman, S. and J. Heritage (2002a). The News Interview: Journalists and Public Figures on the Air. Cambridge: Cambridge University Press.

Clayman, S. and John Heritage (2000b). Questioning presidents: journalistic deference and adversarialness in the press conferences of Eisenhower and Reagan. Journal of Communication 52 (4), 749-777.

Clayman, S. E. and A. Reisner (1998). Gatekeeping in action: editorial conferences and assessments of newsworthiness. American Sociological Review 63 (2), 178-199.

Davies, N. (2008). Flat Earth News. London: Chatto \& Windus.

Eglin, P. and S. Hester (2003). The Montreal Massacre: A Story of Membership Categorization Analysis. Waterloo, ON: Wilfrid Laurier University Press.

Ericson, R. V., P. M. Baranek, and J. B. L. Chan (1987). Visualizing Deviance: A Study of News Organisation. Milton Keynes: Open University Press.

Fairclough, N. (1995). Media Discourse. Arnold: London.

Fairclough, N. and R. Wodak (1997). Critical discourse analysis. In T. A. van Dijk (Ed.), Discourse as Social Interaction, Volume 2 of Discourse Studies: A Multidisciplinary Introduction, pp. 258284. London: Sage.

Fishman, M. (1980). Manufacturing the News. Austin: University of Texas Press.

Fitzgerald, R. and W. Housley (2002). Identity, categorization and sequential organization: the sequential and categorial flow of identity in a radio phone-in. Discourse \& Society 13 (5), 579602.

Fitzgerald, R. and W. Housley (2006). Categorisation, accounts and motives: 'letters-to-the-editor' and devolution in Wales. In J. Wilson and K. Stapleton (Eds.), Devolution and Identity, pp.111126. Aldershot: Ashgate.

Fowler, R. (1991). Language in the News: Discourse and Ideology in the Press. London: Routledge.

Francis, D. W. and C. Hart (1997). Narrative intelligibility and membership categorization in a television commercial. In S. Hester and P. Eglin (Eds.), Culture in Action: Studies in Membership Categorization Analysis, pp. 123-151. Washington, D.C.: University Press of America.

Garfinkel, H. (1967). Studies in Ethnomethodology. Englewood Cliffs, NJ: Prentice-Hall.

Glasgow University Media Group (1976). Bad News. London: Routledge and Kegan Paul.

Glasgow University Media Group (1980). More Bad News. London: Routledge and Kegan Paul.

Watson, P. and C. Greiffenhagen (2009). Press scrums: some preliminary observations. R. Fitzgerald and W. Housley (Eds.), Media, Policy and Interaction, pp. 115-135. Farnham: Ashgate. 
Golding, P. and P. Elliott (1979). Making the News. London: Longman.

Greatbatch, D. (1988). A turn-taking system for British news interviews. Language in Society 17 (3), 401-430.

Greiffenhagen, C. (2008). Unpacking tasks: the fusion of new technology with instructional work. Computer Supported Cooperative Work (CSCW) 17 (1), 35-62.

Greiffenhagen, C. (forthcoming). Analysing media discourse. Forthcoming in F. Devine and S. Heath (Eds.), Doing Social Science: Evidence and Methods in Empirical Research. Palgrave.

Hall, S. (1980). Encoding/decoding. In S. Hall, D. Hobson, A. Lowe, and P. Lewis (Eds.), Culture, Media Language: Working Papers in Cultural Studies, 1972-79, pp. 128-138. London: Hutchinson.

Hall, S. (1982). The rediscovery of 'ideology': return of the repressed in media studies. In M. Gurevitch, T. Bennett, J. Curran, and J. Woollacott (Eds.), Culture, Society, and the Media, pp. 56-90. London: Routledge.

Heath, C. and G. Nicholls (1997). Animated texts: Selective renditions of news stories. In L. B. Resnick, R. Säljö, C. Pontecorvo, and B. Burge (Eds.), Discourse, Tools, and Reasoning: Essays on Situated Cognition, pp. 63-86. Berlin: Springer.

Heritage, J. (1985). Analyzing news interviews: aspects of the production of talk for an overhearing audience. In T. A. van Dijk (Ed.), Discourse and Dialogue, Volume 3 of Handbook of Discourse Analysis, pp. 95-117. London: Academic Press.

Hester, S. and R. Fitzgerald (1999). Category, predicate and contrast: some organizational features in a radio talk show. In P. L. Jalbert (Ed.), Media Studies: Ethnomethodological Approaches, pp. 171-193. Washington, DC: University Press of America.

Housley, W. (2002). Moral discrepancy and 'fudging the issue' in a radio news interview. Sociology 36 (1), 5-21.

Hutchby, I. (1996). Confrontation Talk: Arguments, Asymmetries, and Power on Talk Radio. Mahwah, NJ: Erlbaum.

Jaworski, A., R. Fitzgerald, and D. Morris (2004). Radio leaks: presenting and contesting leaks in radio news broadcasts. Journalism 5 (2), 183-202.

Latour, B. (1987). Science In Action: How to Follow Scientists and Engineers through Society. Cambridge, MA: Harvard University Press.

Laurier, E. (2008) Drinking up endings: conversational resources of the cafe. Language \& Communication 28 (2), 165-181.

Lee, J. R. E. (1984). Innocent victims and evil-doers. Women's Studies International Form 7 (1), 6973.

Payne, G. C. F. (1976). Making a lesson happen: an ethnomethodological analysis. In M. Hammersley and P. Woods (Eds.), The Process of Schooling: A Sociological Reader, pp. 33-40. London: Routledge.

Sacks, H. (1992). Lectures on Conversation (Edited by G. Jefferson). Oxford: Blackwell.

Sacks, H., E. A. Schegloff, and G. Jefferson (1974). A simplest systematics for the organization of turn taking in conversation. Language 50 (4), 696-735.

Schegloff, E. A. (1987). Between micro and macro: Contexts and other connections. In J. C.

Alexander, B. Giesen, R. Münch, and N. J. Smelser (Eds.), The Micro-Macro Link, pp. 207-234.

Berkeley, CA: University of California Press.

Schegloff, E. A. (1997). Whose text? Whose context? Discourse \& Society 8 (2), 165-187.

Schegloff, E. A. (1999a). 'Schegloff's texts' as ‘Billig’s data': a critical reply. Discourse \& Society 10 (4), 558-572.

Schegloff, E. A. (1999b). Naiveté vs. sophistication or discipline vs. self-indulgence: a rejoinder to Billig. Discourse \& Society 10 (4), 577-582. 
Schegloff, E. A. and H. Sacks (1973). Opening up closings. Semiotica 38 (4), $289-327$.

Schenkein, J. (1971). Some Methodological and Substantive Issues in the Analysis of Conversational Interaction. Ph.D. thesis, University of California, Irvine.

Schenkein, J. (1979). The radio raiders story. In G. Psathas (Ed.), Everyday Language: Studies in Ethnomethodology, pp. 187-201. New York: Irvington.

Schlesinger, P. (1978). Putting 'Reality' Together: BBC news. London: Constable.

Smith, A. (1980). Goodbye Gutenberg: The Newspaper Revolution of the 1980s. New York: Oxford University Press.

Tuchman, G. (1978). Making News: A Study in the Construction of Reality. New York: Free Press.

Turner, R. (1972). Some formal properties of therapy talk. In D. Sudnow (Ed.), Studies in Social Interaction, pp. 367-396. New York: Free Press.

van Dijk, T. A. (1988). News as Discourse. Hillsdale, NJ: Lawrence Erlbaum.

White, D. M. (1950). The 'gate keeper': a case study in the selection of news. Journalism Quarterly 27 (3), 383-390. 